\title{
En nivådelt modell for multimodal komposisjonsanalyse av digitalt medierte sakprosatekster
}

\section{A level-divided model for multimodal analysis of digitally mediated factual prose}

Tidsskriftet Sakprosa

Bind 13, Nummer 1

(C) 2021 


\section{Sammendrag}

I denne artikkelen presenterer jeg en nivådelt modell for analyse av teksters komposisjon av flere meningsbærende uttrykksformer. Materialet er to norskfaglige sakprosatekster, i analysen benevnt som bloggutsnitt, produsert av tredjeårs lærerstudenter i et digitalt læringsfellesskap. Modellen er selve objektet for studien, og analysene er hovedbidragene der modellen undersøkes. Sosialsemiotikk er den overordnede teoretiske anskuelsen for undersøkelsen. De meningsbærende uttrykksformene forstås dermed i sammenheng med den sosiale konteksten tekstene befinner seg i, og tolkes ut fra de sosioteknologiske premissene for komposisjonene. Det teoretiske analyseverktøyet er forankret i Gunther Kress og Theo van Leeuwens videreutvikling av Michael Hallidays systemisk funksjonelle lingvistikk (SFL), nærmere bestemt begreper knyttet til visualitet og multimodalitet. Analysene er konkrete eksempler på hvordan den nivådelte modellen kan anvendes, og utfra analysefunn drøftes og begrunnes modellens relevans for å forstå komposisjonell meningsskaping.

\section{Abstract}

In this article I present a level-divided model for analysing multimodal composition. The material is two factualprose-texts referred to as blog excerpts, written by third-year pre-teacher students in the subject of Norwegian in a learning community. The model is the main object of the study, and the analysis of the blog excerpts is the main contribution for examining the model. Social semiotics is the overarching theoretical perspective of the study. The multimodal blog excerpts are thus understood in association with the social contexts in which they are produced and interpreted based on the socio-technological premises of the compositions. Theoretical tools for the analysis are rooted in Gunther Kress and Theo van Leeuwen's further development of Michel Halliday's systemic functional linguistics (SFL), more specifically concepts derived from theories related to 
visuality and multimodality. The analyses serve as concrete examples of how the level-divided model can be used. Based on the findings I will discuss and justify the model's relevance for understanding compositional meaningmaking.

Nøkkelord: sosialsemiotikk; multimodalitet; sakprosa; nivådelt analysemodell; bloggutsnitt; visualitet; komposisjon; informasjonsverdi; visuell fremtredenhet; innramning

Keywords: social semiotics; multimodality; factual prose; level-divided model; blog excerpts; visuality; composition; information value; salience; framing

\section{Om forfatteren:}

Kari Anne Rustand er førsteamanuensis, ph.d., i tekstvitenskap ved lærerutdanningen, Universitetet i Sørøst-Norge. Hovedinteresser er sosiolingvistikk, systemisk funksjonell lingvistikk, multimodalitet og visualitet. 


\section{En nivådelt modell for multimodal komposisjonsanalyse av digitalt medierte sakprosatekster}

\section{Introduksjon}

Formålet med denne studien er å presentere og undersøke en nivådelt modell for analyse av komposisjonell meningsskaping i digitalt medierte sakprosatekster. Den nivådelte modellen er et systematisk rammeverk som kan være til støtte for å analysere alle bestanddelene i en komposisjon, fra det overordnede til det mer spesifikke. Modellen jeg har utarbeidet er selve objektet for studien, og analysene er artikkelens hovedbidrag for å undersøke på hvilke måter den nivådelte analysemodellen eventuelt kan være hensiktsmessig. Eksempelmaterialet som analyseres i artikkelen presenterer jeg som bloggutsnitt. Bloggene ble produsert av studenter i norskfaget i lærerutdanningen, i et digitalt læringsfellesskap. Bloggutsnittene består av det som samlet sett vises på skjermen når et blogginnlegg hentes frem: et innlegg med tittelfelt og sidefelt med ulike navigasjons- og/eller informasjonsfunksjoner. I denne undersøkelsen forutsetter jeg at alt som vises på skjermen kan tilføre mening til innleggene som studentene poster på fagbloggen. Det betyr at hele bloggutsnittets komposisjon, både med designmal og studentinnlegg, påvirker meningsskapingen. Komposisjonen blir dermed satt sammen av flere stemmer (Bakhtin, 1998 [1979]) som gjensidig påvirker hverandre. Et premiss for min utarbeidelse av den nivådelte modellen, er at komposisjonen leses som et helhetlig visuelt bilde, i tråd med Kress og van Leeuwens teorier om å lese bilder (Kress \& van Leeuwen, 2006). Rammen for studien er sosialsemiotisk, og det betyr at meningsskapingen forstås i den sosiale sammenhengen en tekst blir til i (Halliday, 1978). Den sosiale sammenhengen for bloggutsnittene kan knyttes til mange lag, for eksempel institusjonen, lærerstudiet, klassens digitale læringsfellesskap og bloggverktøyet. Jeg søker svar på følgende spørsmål: 
På hvilke måter kan en nivådelt analysemodell eventuelt være hensiktsmessig for å belyse komposisjonell, multimodal meningsskaping i digitalt medierte sakprosatekster?

Siktemålet i denne artikkelen er dermed hovedsakelig metodologisk. For å gi et visuelt inntrykk presenterer jeg i figur 1 ett av de to bloggutsnittene som senere i artikkelen er gjenstand for analyse, samt skisse av utsnittet som illustrerer hva nivåene i analysemodellen viser til. ${ }^{1}$
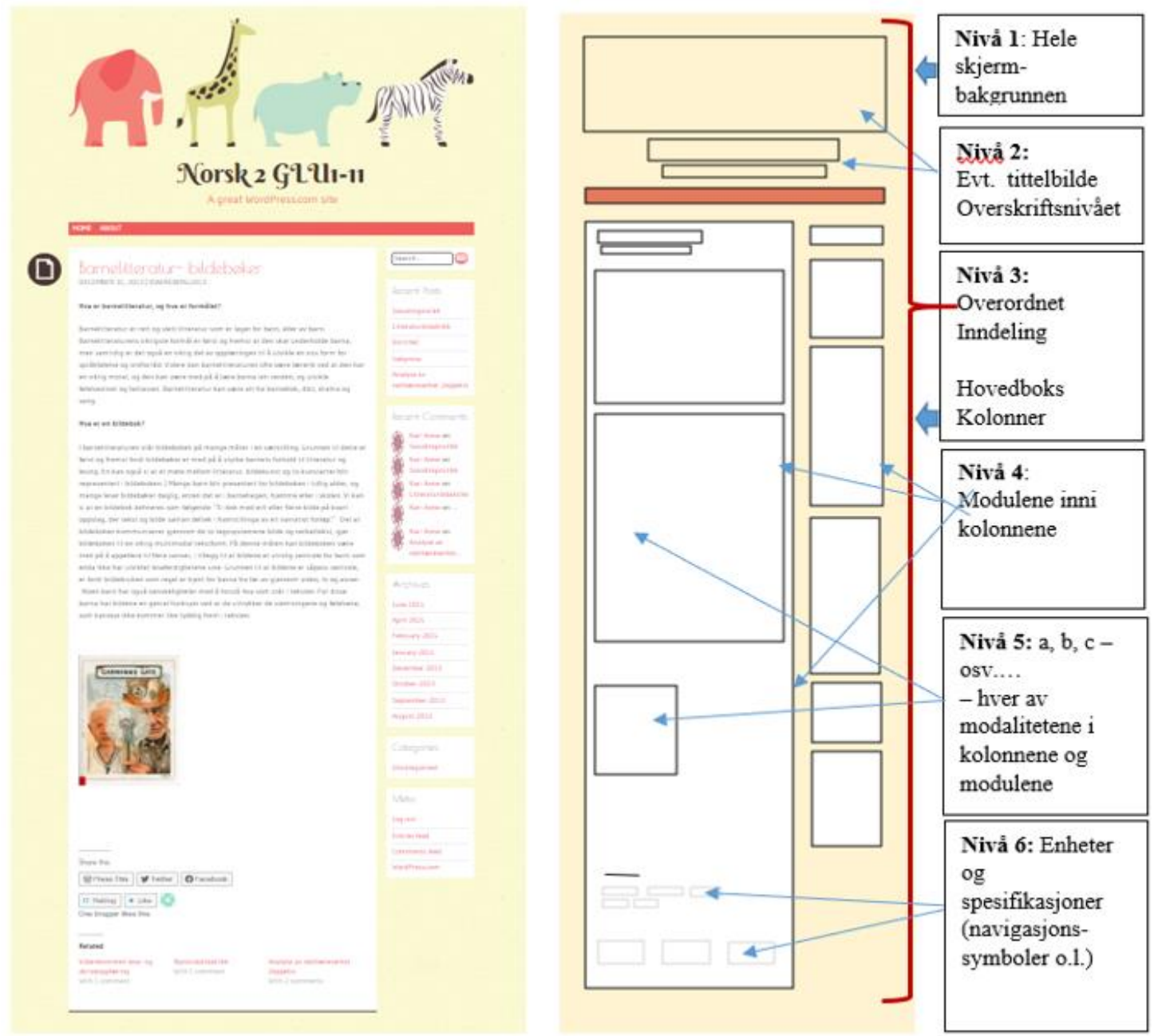

Figur 1: Illustrasjoner av ett av de to bloggutsnittene samt skisser av bloggutsnittene med den nivådelte modellen.

${ }^{1}$ Siden dette er en komposisjonsanalyse, er det ikke nødvendig at verbalteksten er leselig.

K. A. Rustand 
Det overveiende argumentet for at dette er sakprosatekster, er at studenttekstene handler om faglitteraturen i et norskfaglige undervisningsemne i lærerutdanningen. Bloggutsnittenes innhold innfrir dermed Tønnessons (2012) definisjon av sakprosatekster som «[...] tekster som adressaten har grunn til å oppfatte som direkte ytringer om virkeligheten» (s. 34). Videre forstår jeg bloggutsnittene som multimodale sakprosatekster, og støtter meg til Ledin et al. (2019) når de påpeker at «Alla sakprosatexter är multimodala» (s. 4). Modalitetene, de meningsbærende uttrykksformene, i disse digitalt medierte tekstene kan for eksempel bestå av skriftlig verbalspråk, farger, typografi, fotografier, tegninger, video og grafikk, og valg knyttet til plassering, størrelsesforhold og innramming bidrar til å skape ulike former for mening.

Denne studien kan berike sakprosaforskningen på flere måter, siden digitalt medierte tekster stadig endres ved hjelp av ny teknologi (Jewitt, 2006; Kress, 2003; Kress \& van Leeuwen, 2021). Det betyr at vi kontinuerlig bør undersøke multimodalitet i digitale medier, ut fra flere perspektiv. Digitalt medierte tekster kan ha vid geografisk rekkevidde. Det kan få flere konsekvenser, fordi samme meningsskaping kan oppfattes forskjellig i ulike sosiale kontekster, noe som for eksempel kan analyseres frem ved hjelp av kritisk diskursanalyse. Andre eksempler er at ulike verktøy kan inneholde matriser for inkludering eller ekskludering av ytringer, for eksempel i blogg, Facebook eller på Instagram, eller meningsskaping kan påvirkes av holdninger og verdier som produsenter nedfeller i programvaren. I slike tilfeller kan det gjøres sosioteknologiske undersøkelser. En nivådelt modell for systematiske analyser kan justeres og brukes også for andre digitalt medierte tekster enn bloggutsnitt, og uansett analytisk siktemål kan komposisjonsanalyse være hensiktsmessig å gjøre før ytterligere lag av en tekst skal analyseres. Ifølge Jewitt og Oyama (2001) kan en visuell komposisjonsanalyse avsløre det som ikke er synlig ved første blikk. Min antagelse er derfor at den nivådelte analysemodellen kan 
åpne forskerens blikk for innsikt og forståelse. Modellen kan også fungere som en anvendelig struktur for komparative analyser.

Bloggutsnittene i denne studien er hentet fra bloggverktøyet WordPress. En blogg (kortform av web log) kan defineres som en «easy to update website characterized by dated entries displayed in reverse chronological order» (Stefanac, 2006, s. 230). Bloggen er et nettsted for både produsenter og konsumenter, der tekster enkelt kan distribueres og kommenteres. Blogger kan utformes ulikt, og variasjonen av formål er stor. Noen bloggere er kommersielt motiverte, mens andre bloggere først og fremst ønsker å uttrykke seg, formidle, prøve ut ideer, samarbeide og/eller reflektere. Blogg kan ses som en sjanger blant andre sosiale medium, men medieforskerne Lüders, Prøitz og Rasmussen (2010) hevder at blogg snarere kan forstås som et medium som inneholder ulike sjangre, for eksempel politiske blogger, bokblogger, moteblogger eller treningsblogger. Etter mitt syn, er det mulig å hevde at én og samme blogg kan inneholde flere ulike sjangre. I denne studien er det snakk om blogging i norskfaget i lærerutdanningen, hvor formålet med disse sakprosatekstene er det Dysthe et al. (2010) benevner allerede i tittelen på boka som det $A$ skrive for å lære (2010), og kan også forstås som det Melby og Matre (2012) omtaler både i tittelen og i boka forøvrig som $A$ skrive seg inn i læreryrket ( 2012).

Behovet for en nivådelt modell for komposisjonsanalyse må ses i sammenheng med øvrig forskning på digitalt medierte tekster. Å presentere tidligere studier kan belyse hvordan min nivåmodell kan være et svar på udekte behov i feltets forskningshistorie. I det følgende nevner jeg derfor relevant forskning, og knytter dette til denne undersøkelsen. Tradisjonelt har sosialsemiotisk forskning på multimodale tekster handlet om å gi systematiske beskrivelser av ulike modaliteter, og sammenhengen mellom dem, som for eksempel skrift, bilde og lyd (Jewitt \& Kress, 2003; Kress \& van Leeuwen, 2006). Min nivådelte analysemodell kan være et rammeverk for å se hvordan modaliteter er 
designet som en følge av tilgjengelig digital teknologi, og kanskje dermed åpner for å analysere begrensninger og muligheter som fins i verktøyet. Et annet forskningsfelt som vokser frem, har fătt benevnelsen semiotisk teknologi, hvor søkelyset rettes mot hvilke semiotiske interesser som kan være innskrevet i en spesifikk programvare, for eksempel vist ved forskning på presentasjonsverktøyet Power Point (Zhao et al., 2014; Zhao \& van Leeuwen, 2014). Zhao et al. (2014) har blant annet studert sammenhenger mellom programvaredesign og bruken av programvaren. Avgrensede deler av slike studier kan knyttes til min undersøkelse, i den forstand at Zhao et al. (2014) også påpeker designvalg som påvirker hva som trer frem eller utelates (s. 360). Det er nettopp slike spørsmål den nivådelte analysemodellen kan bidra til å oppdage. Min hypotese er derfor at komposisjonsanalyse etter den nivådelte modellen gir oversiktlig tilgang for å tydeliggjøre sammenhenger mellom komposisjon og meningsskaping. Djonov og van Leeuwen (2013; 2018) har også studert multimodalitet og programvare, og her belyser forfatterne viktigheten av å få oversikt over det grafiske designet i en programvare. En nivådelt modell for komposisjonsanalyse kan trolig gi innsikt i hvor multimodalt et bloggutsnitt egentlig er. Jeg vil også nevne min ph.d. avhandling (Rustand, 2019), der jeg utførte en studie av identitetskonstruksjoner i norskfaglige lærerstudentblogger. De innledende komposisjonsanalysene utførte jeg etter nivådelte modeller, som i denne undersøkelsen. Der så jeg nytten av det strukturerende stillaset som modellen min representerer, særlig som et utgangspunkt for videre analyser av tekster.

Videre i artikkelen presenterer jeg først bloggverktøy og konteksten for dette, deretter de teoretiske perspektivene for komposisjonsanalysen og til slutt presenterer jeg kort metode, den nivådelte modellen og de konkrete bloggutsnittene som analyseres. De to bloggutsnittene analyseres ved hjelp av den nivådelte modellen jeg har utviklet, og til slutt oppsummerer og drøfter jeg funnene. 


\section{Blogg og bloggdesign}

Valgene som er nedfelt i bloggverktøyet både påvirker og blir en del av komposisjonen i bloggutsnittene som analyseres i denne studien, og påvirker og former dermed meningsskapingen. Det gjør det nødvendig å belyse visse sider ved programvaren. Gunhild Kvåle (2018) bruker begrepet multimodalt halvfabrikata om designmalene studentene må forholde seg til nå de oppretter en blogg, og hun skriver at «designmalene angir blant annet bakgrunn, fargepalett, visuell ikonografi og typografi» (s. 16o). Designmalene kan karakteriseres som svært brukervennlige, særlig for dagens studentgenerasjon som kan regnes som digitalt innfødte (Prensky, 2001). Tilrettelagte funksjoner viser vei når bloggen etableres. Det multimodale oppsettet blir til gjennom intuitive handlinger ut fra følgende beskjeder som dukker opp på skjermen: «Nettstedstittel settes inn her», «Slagord settes inn her», «Legg til toppbilde» og så videre. Studentene valgte en bloggstil ut fra WordPress-verktøyets 109 gratis-designmaler. Designmalene har ulike stiler som kan være meningsbærende i de to bloggutsnittene jeg analyserer i denne artikkelen. Kvåle (2018) har undersøkt stilene designmalene kan representere, og delt de opp i følgende sju hovedkategorier: den nostalgisk-feminine, den sporty, den høytidsmarkerende, den streite, den rosa, den kosmopolitiske og andre (s. 166).

Kvåle (2018) påpeker videre at «programvarer betraktes som mer enn «digitale verktøy». De er sosiale og semiotiske objekter som setter kritisk viktige premisser for kommunikasjon i vår tid» (s. 161). Bare til en viss grad styres derfor valgene, og dermed også det komposisjonelle resultatet, av individets egne interesser og komposisjonen kan være preget av de semiotiske premissene som er nedfelt i teknologien. Elisabetta Adami (2015) påpeker det samme når hun sier at multimodale valg styres av interessene de store selskapene på markedet måtte ha (s. 204), og dette viser at maktdynamikk kan påvirke sosiale praksiser, og omvendt. Det betyr dermed at programvaren 
kan påvirkes når blogg brukes til produksjon av sakprosatekster i et læringsfelleskap, noe som i neste omgang kan bidra til at produsenten tilpasser bloggverktøyet til bruken.

Zhao, Djonov og van Leeuwen (2014) har utviklet en oversikt over dimensjonene ved blogging som semiotisk artefakt og praksis (s. 355). Bloggproduksjonen vises i den midterste boksen, og står altså i sammenheng med dimensjonene som vises i figur 2 :

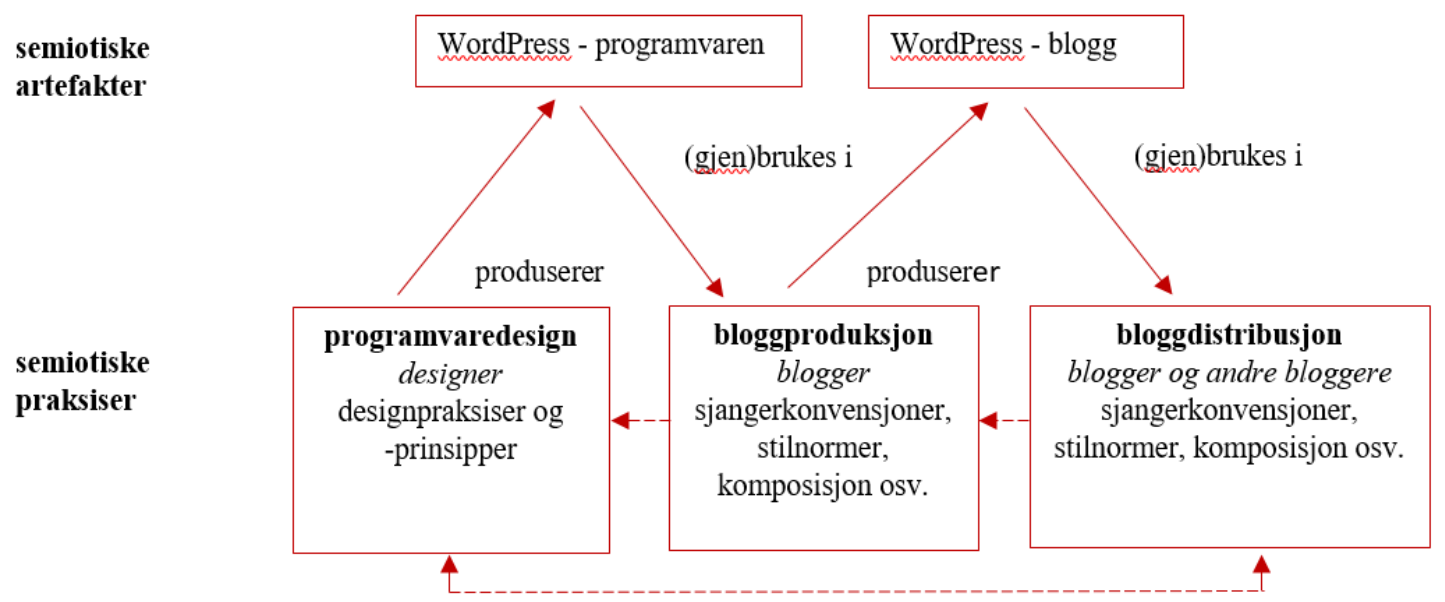

Figur 2: WordPress som multimodal semiotisk artefakt og praksis (Kvåle, 2018, s. 165; Zhao \& van Leeuwen, 2014, s. 355).

Konteksten bloggutsnittene står i kan beskrives som følger. I den nederste raden vises dimensjonene ved blogging som semiotisk praksis. Nederst til venstre illustreres programvare-designernes arbeid med å lage funksjonaliteter i WordPress, som er bloggverktøyet utsnittene i denne studien er hentet fra. Mange faktorer påvirker hvilke ressurser som legges inn i programvaren, for eksempel designpraksiser og prinsipper, sosiale forestillinger og mål. Den første semiotiske artefakten produseres av programvare-designerne og vises i øverste rad. Designene som ligger innbakt i WordPress (gjen)brukes av bloggerne i det de oppretter egen blogg. Sjanger- 
og stilkonvensjoner og de mulige kompositoriske sammensetningene, har derfor innvirkning på studentenes produksjon og produkt. En ferdig blogg blir deretter det tredje leddet i den semiotiske praksisen, som i dette tilfellet er en WordPress-blogg. Den stiplede linjen nederst i figuren illustrerer at bloggernes bruk av egen og andres blogger igjen kan påvirke oppdateringer og endringer som programvare-designere gjør.

\section{Sosialsemiotikk, multimodalitet, visualitet og design}

Semiotisk praksis er i endring, blant annet fordi teknologien stadig endres. Feltene multimodalitet og visualitet er utviklet innenfor den sosialsemiotiske forskningstradisjonen (Björkvall, 2009; Jewitt, 2014; Kress, 2010; Kress \& van Leeuwen, 2006; van Leeuwen, 2005), og grunntanken i sosialsemiotikk er at en tekst er en semantisk enhet, at tekst består av mening og ikke først og fremst bare ord og setninger (Halliday \& Hasan, 1989, s.10). Meningsskapingen er nøye knyttet til sosial og kulturell kontekst.

Bakhtin (1998 [1979]) benevner konteksten som fins nedfelt i teksten som stemmer og forklarer at en analyse av ytringer bare er mulig når man gjør analyse: «[...] av heile ytringa og berre i den kjeda av talekommunikasjon denne ytringa er ei uløyselig ledd i» (s. 44). I denne sammenhengen kan viktig kontekst, altså tidligere «talekommunikasjon», være knyttet til institusjonen, lærerutdanningen og de nedfelte holdningene og verdiene som er innbakt $\mathrm{i}$ programvaren.

Begrepet design er vesentlig i denne studien. Tradisjonelt har design handlet om formen til et produkt, og kan også betegne selve formgivingsprosessen. Innenfor semiotikken har Bill Cope og Mary Kalantzis (2000) hevdet at det å designe mening handler om mer enn bare det å skrive tekst, og i bloggutsnittene er det tydelig at studentene aktivt tar i bruk det store tilbudet av semiotiske modaliteter. I denne artikkelen brukes designbegrepet for å under- 
streke de innovative og kreative sidene ved meningsskaping, i tråd med Gunther Kress' (2010) definisjon av begrepet. Kress sier at designhandlinger kan forstås som prosesser der re-arrangering skjer: «[...] elements remain while their ordering in an arrangement is changed» (s. 129). Dette forstår jeg som omforming eller gjenbruk der ny mening kan oppstå. Mening oppstår, ifølge Gunther Kress (2003), når noen fortolker ytringene. Komposisjon er et 'grep' for å skape mening, og analysene av komposisjon bygger på fortolkning i hermeneutisk forstand.

\section{Visuell komposisjon}

Komposisjon kan sies å være det visuelle tilsvaret til det Michael Halliday benevner som tekstuell metafunksjon i verbalspråket (Halliday \& Matthiessen, 2004). Hver av modalitetene må bindes sammen til helhetlig meningsskaping (kohesjonsmekanismer), og meningen som skapes bør stå i forhold til annen multimodal mening i de tekstlige omgivelsene. I tillegg står den multimodale meningsskapingen i en kontekstuell sammenheng som virker inn på hvordan vi forstår meningsskapingen i tid og rom.

Kress og van Leeuwens (2021, s. 181-182) tre prinsipper for å avdekke komposisjon er anvendelige i denne studien: informasjonsverdi, visuell fremtredenhet og innramming. Disse tre prinsippene beskriver de visuelle elementene og forholdet de har til hverandre. 


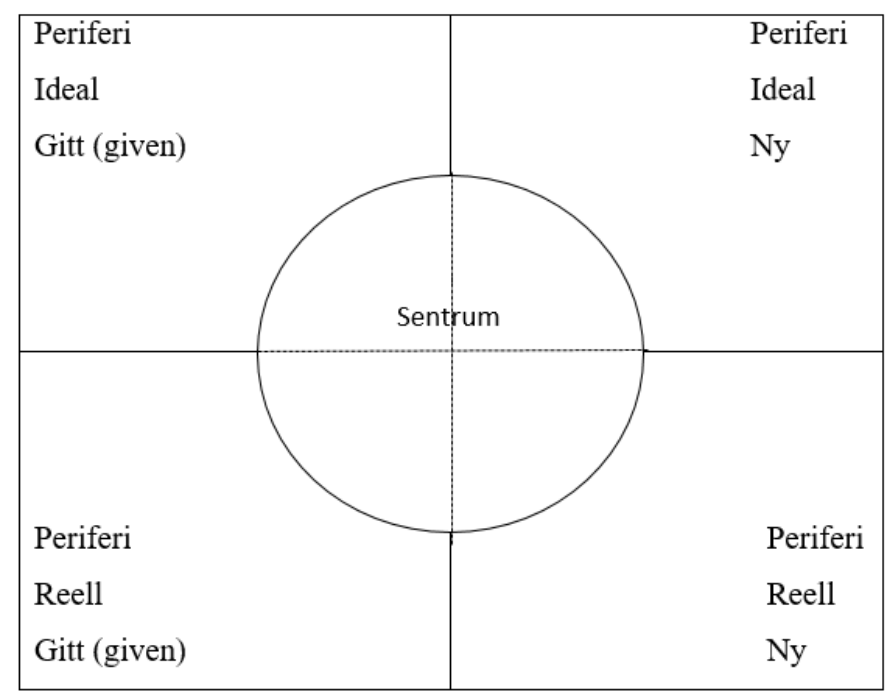

Figur 3: Det visuelle rommets informasjonsverdi (Kress \& van Leeuwen, 2021, s. 203).

Når det gjelder informasjonsverdien, er det elementenes plassering som beskrives. Her kan det være av betydning hvilke soner elementer er plassert i: venstre eller høyre, topp eller bunn, senter eller ytterkant. Gitt og nytt er også anvendelige begreper. Langs horisontal akse i figur 1 ser vi at det som er kjent for leseren, gitt, ofte er plassert til venstre, mens det nye ofte er plassert til høyre. Det gitte er ofte selvforklarende og allmenngyldig. Det nye er opplysninger leseren ofte må tillegge ekstra oppmerksomhet, fordi dette representerer noe leseren ikke vet fra før eller at det er oppsiktsvekkende på ett eller annet vis. Den vertikale aksen viser en fordeling mellom ideell og reell. Ideell er gjerne opplysninger eller informasjon som betraktes som generalisert og ønsket informasjon, mens det reelle representerer detaljert og spesifikk («sann») informasjon. Sentrum-periferi-dimensjoner kan også ha betydning, der sentrumsplassering viser noe som er viktig mens perifer plassering signaliserer at et element ikke er fullt så viktig. Visuell fremtredenhet handler om elementer som tiltrekker seg leserens oppmerksomhet. Plassering, størrelse, kontraster/skarphet er måter å skape visuell fremtredenhet på. 'Vekten' til ulike elementer kan vurderes, for noen elementer fremstår som 'tyngre' enn andre. Kulturelle symboler eller menneskelige figurer kan ha visuell tyngde. Balanse, harmoni og rytme kan øke 
sannsynligheten for det Kress og van Leeuwen (2021) sier kan «gripe leserens oppmerksomhet» (s. 211).

Det tredje prinsippet er tilstedeværelse eller fravær av innramming. Det kan handle om synlige skillelinjer, fargekontraster eller andre elementer som signaliserer nærhet eller avstand. Tomme rom kan opptre som et skille. Det kan også bokser eller linjer som skiller én modalitet fra en annen. Ifølge Kress og van Leewen (2021) finnes det mange måter å skape sammenheng på: fargebruk, innramming av for eksempel en gruppe mennesker eller blikk- eller bevegelsesretninger (vektorer). En vektor, i form av at et blikk rettes mot leseren, kan ha to funksjoner: Leseren anerkjennes ved at det skapes et visuelt «du» og et visuelt «krav» kan stilles til leseren.

Komposisjon er uløselig knyttet til Kress' begrep affordans (gjengitt av Jewitt, 2014, s. 456). Begrepet affordans betegner mulighetene og begrensningene hver enkelt modalitet har for å kunne uttrykke mening i sosiale og kulturelle sammenhenger. Funksjonell spesialisering betegner den kommunikative oppgavefordelingen mellom modaliteter. For eksempel kan et bilde presentere en situasjon, mens verbalteksten til bildet uttrykker og utdyper hva som faktisk skjer. Funksjonell tyngde er når én modalitet bærer mer informasjonsansvar enn andre modaliteter. Bredden på kolonner kan tenkes å være et vesentlighets-hierarkisk signal. Det betyr at innholdet i brede kolonner ofte tillegges større tyngde, enn smale eller små kolonner.

\section{Metode, nivådelt modell og materiale}

Dette er en kvalitativ utforskning av en nivådelt modell, og modellen anvendes på to komposisjonsanalyser. Analyser av komposisjon er gjerne mer deskriptive i formen enn en bredere (og dypere) tekstanalyse, der mer enn komposisjonell mening analyseres. Nivåene har jeg definert, justert og tilpasset $\mathrm{i}$ et tidligere forskningsarbeid (Rustand, 2019). Modellen har seks 
nivåer. Jeg velger begrepet nivåer, fordi modellen bidrar til at den som analyserer beveger seg fra det overordnede til det mer spesifikke i en analyse. Nivå 1 omfatter hele skjermbakgrunnen, der farge, tekstur og kontrast kan ha meningsskapende betydning. Nivå 2 er der tittelbilde/tittelfigur/visuell 'overskrift' og overskriftsnivå befinner seg. Dette nivået er gjennomgående, det vil si at disse elementene er konstante og dukker opp uavhengig av hvilket innlegg leseren trykker seg inn på i bloggen. En egenskap ved nivå 2 kan være at meningsskapingen kan få ulik betydning, avhengig av hvilket innhold som vises i den dynamiske innleggskolonnen (posten). Nivå 3 er den overordnede inndelingen av selve bloggen, altså antall hovedkolonner, plassering, bredde og lignende. I disse bloggutsnittene er det snakk om to vertikale hovedkolonner. Nivå 4 har jeg definert som «modulene» inni hovedkolonnene. Moduler kan her forstås som metaforer for fysiske «lagringsbokser» i det visuelle rommet. De kan ha ulik størrelse (kvadrater eller rektangler) og farge. Noen er rammet inn av linjerte ytterkanter, andre har ingen visuell innramming. Nivå 5 viser til hver av modalitetene som er implementert inn i modulene (nivå 4) og kan benevnes ved hjelp av bokstaver (a, b, c). Iblant kan en modul (i en kolonne) romme flere modaliteter, andre ganger kan en modalitet, for eksempel et bilde eller en tegning, tre uavhengig frem uten å tilsynelatende høre til innenfor en modul. Nivå 6 består av trykkaktive 'knapper' som fører leseren til for eksempel Facebook, Twitter eller interne enheter som RSS-støtte (abonnerings-tjeneste). Det jeg kaller spesifikasjoner er trykkaktiv tekst som fører leseren til kommentarfelt under hvert innlegg, der diskusjoner eller poeng kan spesifiseres eller diskuteres, eller trykkaktiv tekst som fører til nylige eller tematisk lignende innlegg i samme blogg.

Studentene utviklet bloggene gjennom ett helt studieår. Det totale materialet består av 21 individuelle blogger med 334 innlegg (poster). Hver student postet mellom 15 til 24 innlegg på egen blogg, og det var stor variasjon når det gjaldt å teste ut tekster og tekstsjangre. Minimumskriteriet for bloggingen var 
minst ett innlegg knyttet til hvert av de 12 hovedtemaene i det norskfaglige emne.

\section{Analyse av komposisjonen i to bloggutsnitt}

\section{Bloggutsnitt 1}

I figur 4 vises bloggutsnitt 1, en stilisert utgave av bloggutsnittet og den nivådelte analysemodellen som utgjør materialet for komposisjonsanalysen.
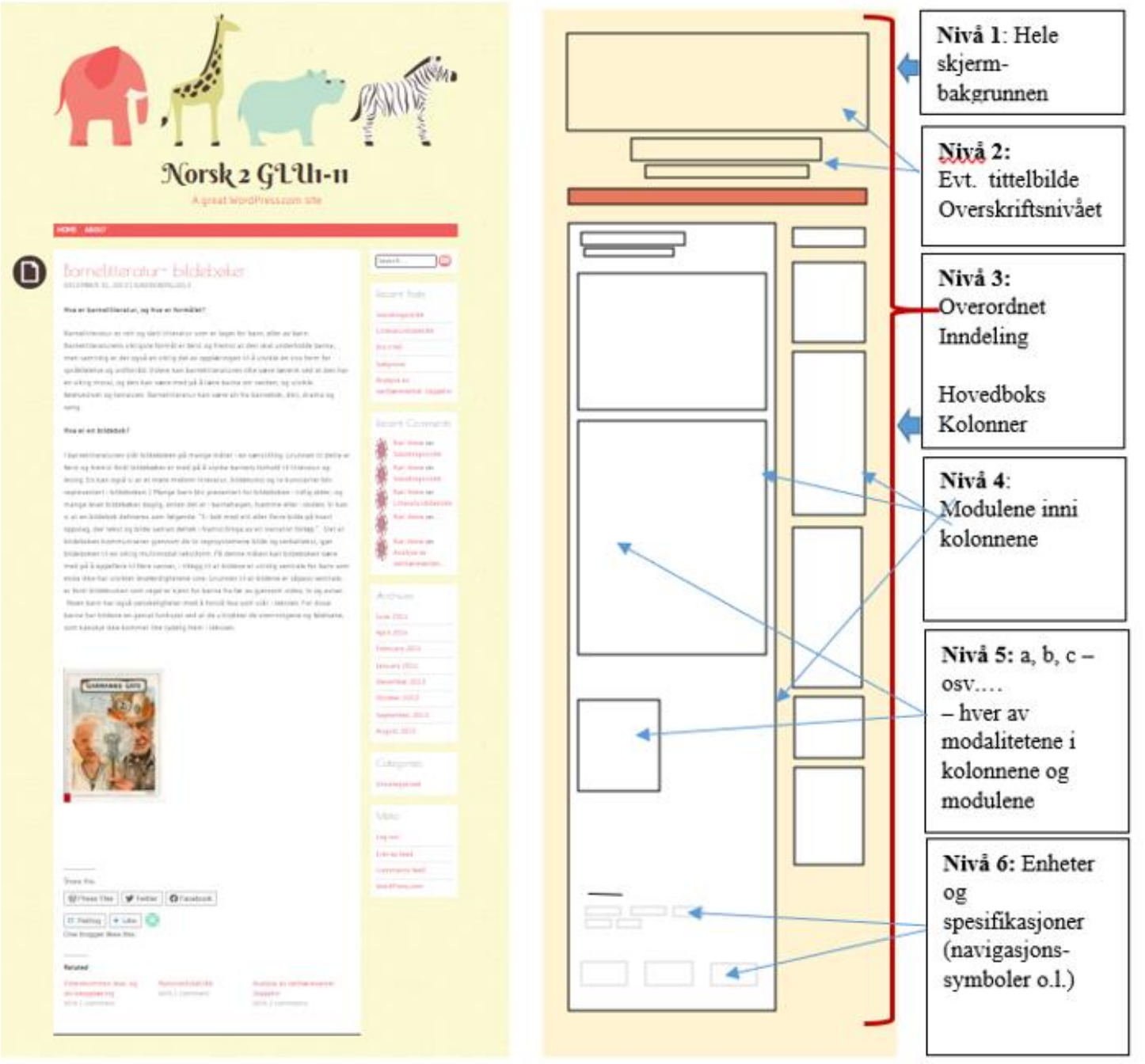

Figur 4: Blogginnlegget til venstre og den stiliserte nivådelte modellen til høyre 
Studenten har her valgt en lys gul skjermbakgrunn (nivå 1). Bloggen rammes inn av en gul farge, og samme gulfargen dukker opp uansett hvilket innlegg som vises. Sammenheng skapes ved at gulfargen indikerer at leseren befinner seg innenfor denne bloggen, selv om innleggene skifter. Avhengig av hva hver enkelt leser opplever, kan den gule fargen oppfattes enten som en farge som løfter frem informasjonen i de hvite kolonnene eller en farge som fører blikket ned/inn i de hvite kolonnene. Gult og hvitt skaper kontrast. Gult rammer inn og skaper gjennomgående helhet. De hvite kolonnene byr på informasjon som leseren kan gå i dialog med, enten ved å lese verbaltekst, tolke bilder eller navigere.

Informasjonsverdien er knyttet til hvordan elementene er plassert i ulike soner, og om informasjonen i sonene er gitt, altså kjent for leseren, eller $n y$, altså ukjent informasjon for leseren (Kress \& van Leeuwen, 2006). Plasseringene av informasjonselementene når det gjelder gitt og nytt kan beskrives på flere måter. Horisontalt (høyre/venstre) kan gitt/nyttplasseringen oppfattes som omvendt av det Kress og van Leeuwen viser i sin figur (se s. 7, figur 1), for her kan verbalteksten og bildemodaliteten i studentinnlegget (nivå 5) bære frem ny informasjon, mens høyre kolonne med de vertikale boksene (nivå 3) kan sies å representere det som er gitt, dersom vi forutsetter at navigasjonsmulighetene kan forstås som kjent for rutinerte bloggere og blogglesere. Om vi vurderer den vertikale aksen, ideell og reelldimensjonen, kan tittelbildet (nivå 2) leses som mer abstrakt knyttet til akkurat dette innlegget, siden tittelbildet også befinner seg over hvert innlegg i bloggen. Tegningen av Garman- «frimerket» (nivå 5) kan oppfattes som reelt, fordi det er et direkte eksempel på barnelitteraturen som omtales i akkurat denne verbalteksten. Venstre og høyre kolonne (nivå 3) innrammes begge av den gule bakgrunnen, og på den måten avgrenses de fra hverandre.

Tittelbildet og overskriftsnivået (nivå 2) har samme gule bakgrunn som bloggen for øvrig. Tittelbildet har dermed ikke en markant og kontrastert 
bakgrunnsfarge, men er integrert i den helhetlige bakgrunnsfargen. Visuelt gir dette et tydelig signal om at både gulfargen, den verbaltekstlige hovedtittelen og tittelbildet er en del av det gjennomgående designet. Alle dyrene i tittelbildet vender nesa mot høyre: rosa/orange elefant, gul giraff med sorte prikker, turkis flodhest og svart og hvit sebra. Dyrene har et lekedyr-aktig preg og fremstår som visuelt fremtredende. Dyrene er altså et blikkfang som i denne konteksten kan oppfattes som fengede, aldersadekvate lekedyr for elever i de laveste trinnene i grunnskolen, og tegningene av dyrene fungerer som en påminnelse om hvilke skoletrinn studenten utdanner seg til å undervise ved. Dette er tittelbildet for en norskfaglig blogg, og kan derfor også forstås som illustrasjoner som kan sette i gang fantasien omkring dyr fra det afrikanske kontinentet. Dermed kan tittelbildet også forstås som en ideillustrasjon for elevers muntlige eller skriftlige fortellinger. Den verbaltekstlige tittelen er: Norsk 2, GLU 1-XX. Bloggen er altså en fagblogg fra norskemne 2. GLU er et akronym for grunnskolelærerutdanning og $1-X X$ (årstall) formidler at bloggeren er student ved utdanningen for grunnskolens 1.- 7. trinn. XX (årstallet) formidler hvilket årstall studenten startet opp ved lærerutdanningen.

I venstre kolonne ligger både tegningen og den verbaltekstlige informasjonen studenten ønsker å formidle (nivå 5). Den venstre kolonnen er bredere enn kolonnen til høyre. At innleggskolonnen er bredest, tolker jeg her som et komposisjonelt signal om at den har funksjonell tyngde og dermed bærer informasjonsansvaret i bloggen. Overskriften er: Barnelitteratur bildebøker, og deretter presenteres leseren for to tekstavsnitt med mellomoverskriftene Hva er barnelitteratur, og hva er formålet? og Hva er en bildebok? Til sist reflekterer bloggeren omkring forholdet mellom verbaltekst og visualitet (nivå 5). Verbalteksten har et lærebokpreg, og kan forstås som en tekst bloggeren har skrevet for å lære om barnebøker/bildebøker og for å dele sin lærdom med medstudenter i læringsfellesskapet. 
Under verbaltekstene vises omslaget til bildeboka Garmans gate (nivå 5). Garmann nevnes ikke i verbalteksten, men bildefunksjoner knyttet til det å vise stemning og følelser nevnes. Bildet kan forstås som et visuelt eksempel på verbaltekstinnholdet. Garman i figur 5 engasjerer oss med blikket sitt, en vektor skaper en «se meg»-funksjon mellom Garmans øyne og leserens, og leseren «trekkes inn» i Garmans verden (interpersonell metafunksjon).

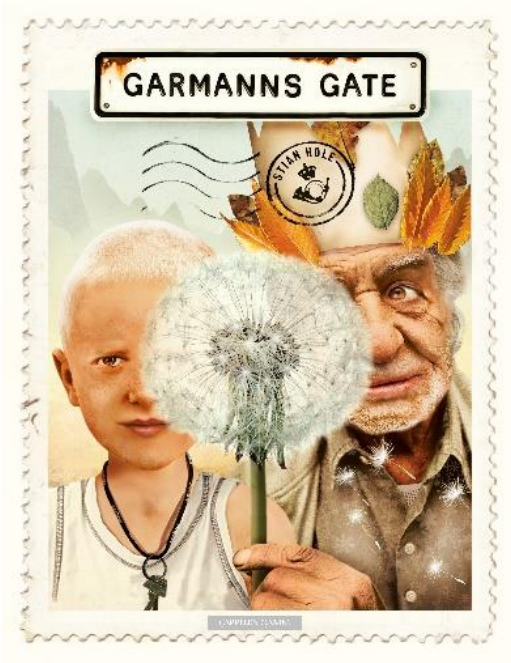

Figur 5: Omslaget til Garmans gate av Stian Hole, (C) Cappelen Damm.

Den høyre kolonnen består egentlig av seks moduler (widgets) med spesifikke navigeringsfunksjoner (nivå 5). Som nevnt, bidrar det gjenkjennbare navigasjonsdesignet til at det høyre, vertikale feltet kan ses som gitt. De ulike modulene til høyre kan bloggeren velge ut fra en mengde moduler med ulike funksjoner, flere av disse har integrerte, predefinerte funksjonmatriser (de beskriver jeg nærmere snart). I den høyre kolonnen ledes det også til informasjon som kan forstås som ny. I denne bloggen ligger det for eksempel et søkefelt øverst. Søkefeltet gjør det mulig for bloggprodusent og bloggleser å søke internt i bloggen ved hjelp av stikkord, fraser eller setninger. Søkefeltet gir altså muligheter for å søke frem ny informasjon, eller informasjon som har sammenheng med innlegget som vises til venstre. Under søkefeltet ligger det ei liste med trykkaktive, tidligere innleggs-titler (den siste først). Det nye her 
kan sies å være informasjon om hvilke andre temaer det er skrevet innlegg om på bloggen. På denne måten synliggjøres det at det fins en visuell romlighet i bloggen, med forgreininger til andre tekster. Deretter følger ei liste med trykkaktive pekere til de sist publiserte kommentarene fra andre bloggere. For hver peker til kommentar vises først et ikon, deretter navnet til den som har kommentert og deretter tittelen på innlegget vedkommende har kommentert. Ikonet genereres automatisk, og kan være ulikt fra individ til individ. Dette betyr at person og ikon kobles sammen. For akkurat dette innlegget, er rekken av ikoner de samme. Det gir visuelle signaler om at det er samme person som har lagt inn kommentarer til flere innlegg. Under der igjen vises et arkiv der hver måned er skrevet med verbaltekst. Ved hjelp av et tastetrykk på en vilkårlig måned, føres leseren til blogginnleggene som ble publisert akkurat den måneden. Nest nederst er det en modul som heter kategorier. Funksjonen forutsetter at bloggeren har kategorisert ulike innlegg med ett eller flere trykkaktive stikkord i ei liste. Helt nederst er det en modul som heter meta. Der ligger logg inn/logg ut-funksjoner, peker til en WordPress-oversikt over andre blogger, og feed-funksjoner som gir innsikt i programmeringen for innlegg og kommentarer. Alle disse modulene er omtrent like i andre designmaler, men i noen maler kan innleggsiden og modulsiden ha byttet plass. Modulene kan også befinne seg under innleggene, i de tilfellene der designmalen bare viser én bred vertikal innleggskolonne. På nivå 6 ser vi funksjonelle navigasjonsknapper til WordPress, Twitter og Facebook. Nederst på nivå 6 presenteres trykkaktive titler til tre tidligere innlegg på denne bloggen.

Sammenfattende kan det påpekes at de to kolonnene i dette bloggutsnittet har ulikt betydningspotensial. I venstre kolonne finner vi studentinnlegget som her er knyttet til temaer innenfor norskfaget, mens i høyre kolonne befinner de mer administrative modulene seg, med nevnte navigasjonsfunksjoner, oversiktskalender, innloggingsknapper og så videre. 


\section{Bloggutsnitt 2}

I figur 6 vises bloggutsnitt 2, en stilisert utgave av bloggutsnittet og den nivådelte modellen som utgjør materialet for komposisjonsanalysen.

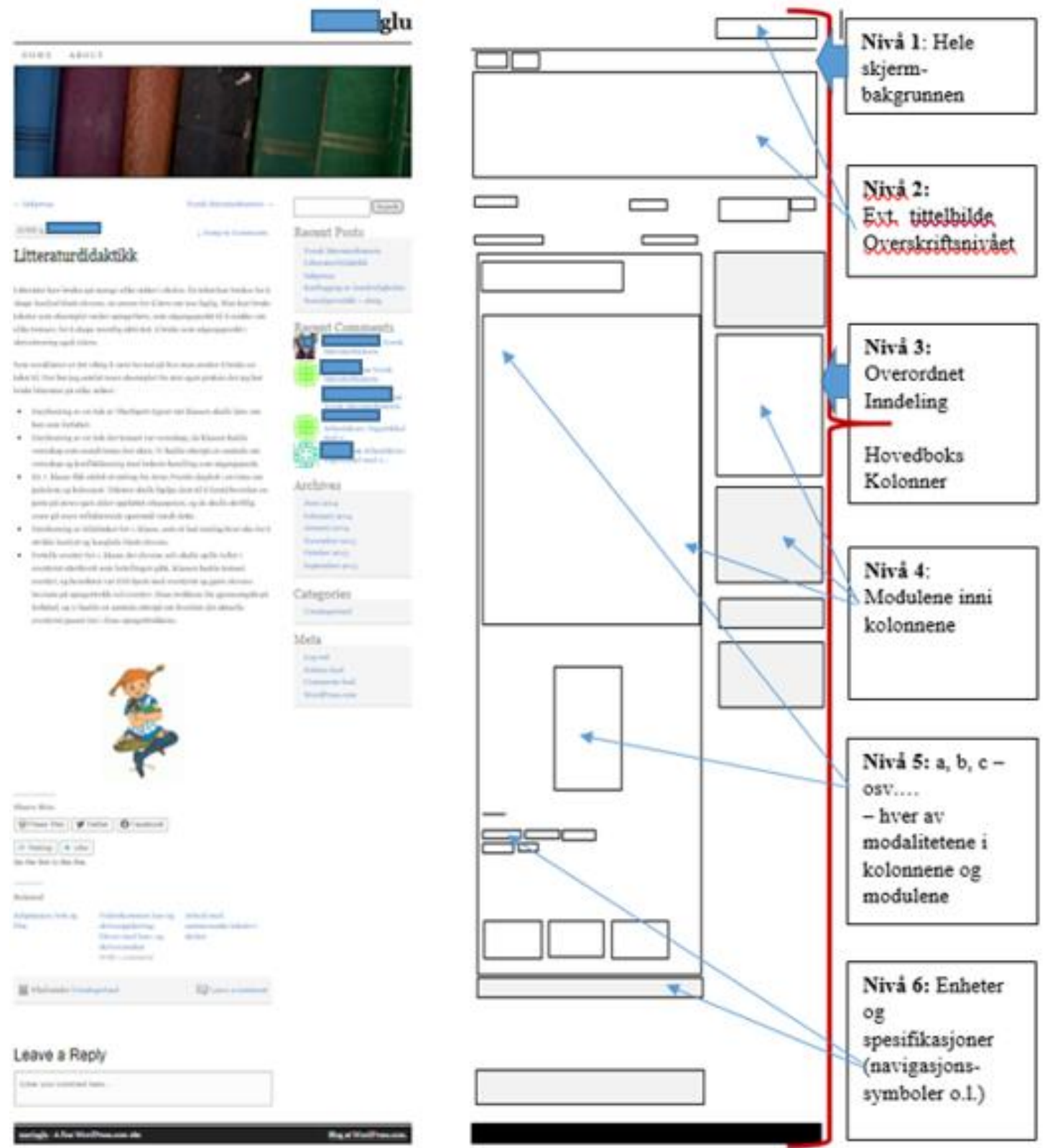

Figur 6: Blogginnlegget til venstre og den stiliserte nivådelte modellen til høyre 
Studenten har her valgt hvit bakgrunn (nivå 1), og noen av modulene (widgets - nivå 4) i høyre kolonne og nederst, er svakt grå. På denne måten er kontrastene vage. Det hvite feltet mellom de to kolonnene skaper likevel en avgrensning som bidrar til at de to kolonnene fremstår som to selvstendige, innrammede enheter (nivå 3). Overskriften er fornavnet på bloggeren samt akronymet glu (grunnskolelærerutdanning). Studentnavnet er anonymisert her. Tittelbildet viser gamle bokrygger og kan forstås som en illustrasjon til tittelen på selve blogginnlegget: Litteraturdidaktikk. I denne konteksten leder bokryggene tankene til tradisjonell skjønnlitteratur. Bokryggene er i en mørk fargeskala: grønn, sort, blå og brun. Bildet trer visuelt frem i bloggutsnittet og bidrar til å sette en rolig stemning (nivå 2). Her skaper fargene en kontrast til den hvite bakgrunnen, og størrelsen er en ressurs som bidrar til at bildet blir et blikkfang. Bildebredden bidrar til å avgrense den horisontale bredden for kolonnene under. Den overordnede horisontale inndelingen er todelt. Kolonnen til venstre er den mest verbaltekstlige bolken, og kan sies å ha en funksjonell spesialisering (nivå 3). Selve innlegget representerer her det nye, gjennom at studenten i to avsnitt presenterer innspill om hva litteratur kan brukes til i skolen. Deretter presenteres fem kulepunkter med ideer til praktiske undervisningsideer knyttet til bruk av litteratur i klasserommet. I verbalteksten presenteres ikke Pippi. Her kan bildet av Pippi forstås som en illustrasjon av barnebøker generelt (figur 7).

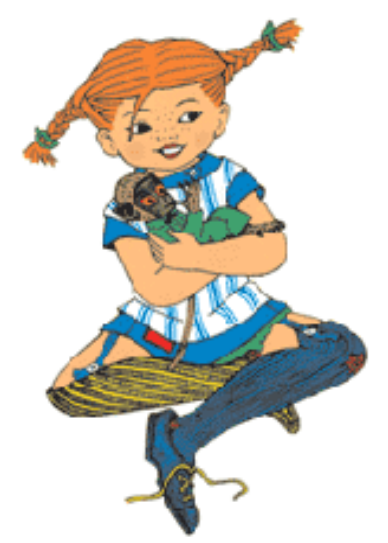

Figur 7: Pippi, tegnet av Ingrid Vang Nyman. (C) The Astrid Lindgren Company, Sverige. 
Pippi er visuelt fremtredende, sammen med tittelbildet. De to bildene kan sees i sammenheng. Leseren vil kunne oppleve at Pippi-bildet er en konkretisering av hva som kan finnes inni tradisjonelle barnebøker, selv om den reelle Pippi-bokryggen er mer fargerik og tynnere enn de som presenteres i tittelbildet. De komposisjonelle elementene kan dermed sies å ha en semantisk sammenheng. Knyttet til informasjonsverdi kan tittelbildet (nivå 2) oppfattes som abstrakt i henhold til akkurat denne verbalteksten (ideelt), siden tittelbildet vises over alle innlegg i bloggen, mens Pippi-bildet kan ses som et bilde med sterk relevans til det verbaltekstlige innholdet (reelt). Modalitetene i denne kolonnen er altså verbaltekst og bilde (nivå 5), og innleggs-kolonnen er den bredeste i bloggen. Det kan indikere at denne kolonnen er mer vesentlig enn andre. Ressursene som avgrenser er den usynlige innrammingen av innleggs-kolonnen, avstanden mellom kolonnene og den lille hvit-grå-kontrasten mellom verbalteksten i venstre kolonne og de grå modulene (widgets) i kolonnen til høyre. Sammenhengen skapes ved hjelp av den hvite bakgrunnen (nivå 1) som helhetlig rammer inn tittel/tittelbildet og kolonnene med innhold. Under Pippi-bildet finner vi gjennomgående, trykkaktive navigasjonsknapper som gjør det mulig å dele innlegget på Twitter og Facebook, trykke seg inn til WordPress-tjenester (editor), reblogge og like innlegget (nivå 6). Nederst kan leseren navigere til tre andre innlegg i denne bloggen (nivå 6).

I den overordnede inndelingen (nivå 3) finner vi også høyre kolonne. Overordnet kan den karakteriseres som det gitte. Det er fordi modulene kan antas kjente for bloggere og blogglesere. Det er likevel slik at blogglesere kan navigere videre til innlegg som gir leserne $n y$ informasjon. For eksempel finner vi muligheter til å navigere til ny informasjon i fire av modulene (nivå 4). Den første modulen har tittelen Recent Posts og viser til tidligere innlegg gjennom en vertikal punktliste med fem trykkaktive titler (nivå 4). Den neste modulen har tittelen Recent Comments, og viser til en liste med fem kommentarer lagt inn av andre bloggere (nivå 4). Trykkaktiv verbaltekst fører 
leseren til kommentarene. Her ser vi at den første pekeren til kommentaren er lagt inn av en medblogger som identifiserer seg ved hjelp av bilde, navn og verbaltekst med tittelen på innlegget som er kommentert. Andre og fjerde pekere til kommentarer er lagt inn av samme person. Ikonet er en mønstret, grønn firkant, deretter ser vi identifikasjonsnavnet til medbloggeren og tittelen på blogginnlegget som er kommentert. Den tredje kommentaren viser til lenker innad i bloggfellesskapet, mellom to andre innlegg med samme titler, men der innholdet i de to ulike bloggene utvider og utfyller hverandre. Den femte pekeren til en kommentar viser en mørkere grønn, mønstret logo, medbloggerens initialer og tittelen på innlegget vedkommende har kommentert på. Deretter følger en modul med tittelen Archives, der trykkaktive navn på seks måneder vises under hverandre. Leseren kan trykke seg inn på ønsket måned for å få en oversikt over innleggene som ble lagt inn akkurat den måneden. Modulen under heter Categories. Bloggeren kan legge inn stikkord som bidrar til at innlegg automatisk kategoriseres. Her har ikke bloggeren valgt å benytte seg av denne modulen. Siste modul heter Meta, og gir bloggeren mulighet til å logge ut/inn på egen blogg, og ellers gjør tre vertikale, interaktive verbaltekster det mulig å logge seg inn på innleggsfeeden, kommentar-feeden og navigere til WordPress-websiden.

\section{Diskusjon av komposisjonell meningsskaping}

I denne tekstdelen diskuterer jeg momenter knyttet til den komposisjonelle meningsskapingen i de to bloggutsnittene, for å vise hvordan modellen kan bidra til å svare på hva slags meningsskaping disse digitalt medierte sakteksten inneholder. Overordnet består begge bloggutsnitt av særegne kjennetegn som gjør at det er lett å vite om man befinner seg innenfor eller utenfor bloggen. De to tittelbildene formidler hver sin stemning, og disse stemningene bidrar til at leseren kan danne seg et grunnleggende inntrykk av meningsskapingen i bloggutsnittet. Den første titteltegningen gir et lekent inntrykk som, kombinert med verbalteksten «Norsk 2 GLU», formidler at innholdet er 
produsert i lærerutdanningen og knyttet til norskfaget i småskolen. Leseren får dermed et inntrykk av hvilken kontekst bloggen er skapt innenfor, nemlig at en lærerstudent skriver seg inn i småskolelærer-rollen. Valget av en jentenormativ stil gir inntrykk av at studenten er seg bevisst at teksten produseres i en grunnskolelærerutdanning rettet mot trinn 1-7, en barnlig stil, og valget av designmal kan antyde at forfatteren er en kvinnelig student med blikk for elevene på trinnene der hun skal undervise. Tittelbilde i det andre bloggutsnittet er av tradisjonelle, gamle bokrygger med «GLU» skrevet øverst, noe som leder tankene til grunnskolelærerutdanning og litteratur. Dette bloggutsnittet har trekk fra den streite stilen (Kvåle, 2018, s. 169). Det kan tolkes som at studenten identifiserer seg som en student i høyere utdanning, og stilen gir et akademisk og seriøst inntrykk. Felles for de to bloggutsnittene er at tittel og tittelbilde på nivå 1 og 2 gir informasjon om tema og kontekst. Dette tyder på at flere lag av mening kan nedfelles i tittelbilde-nivået.

Inndelingen i kolonner (nivå 3) viser i begge bloggutsnitt at studentinnlegg ligger til venstre, mens navigasjonsmulighetene ligger til høyre. Til tross for særegenheter i hvert av utsnittene, kan felles struktur bidra til å styrke opplevelsen av at studentene hører til innenfor samme læringsfellesskap. I begge bloggutsnitt er verbaltekstene dominerende i innleggene til venstre (nivå 5), mens tegningene under verbalteksten ser ut til å være illustrasjoner som understreker poeng i verbalteksten. Det kan være et svar på at studentene oppfatter at verbaltekst ofte er den mest brukte modaliteten i akademiske tekster. Det kan også antyde at studentene fremdeles er usikre på bruken av mediespesifikke virkemidler, som lenking og visuell meningsskaping. I kolonnen til høyre i designene (nivå 4) kan studentene velge hvilke vertikale bokser de ønsker å sette inn i denne kolonnen, og hver av boksene har preproduserte funksjoner som trykkaktiv tekst, ikoner knyttet til andre blogger og lignende. I begge bloggutsnitt vitner utvalget av bokser på høyresiden om at studentene bruker blogg som en læringsplattform. Kommunikative 
navigasjonsfunksjoner er fremtredende, ved at det vises til andres blogger, eget bloggarkiv og til kommentarfelt med kommentarer fra medstudenter.

På nivå 6 bekreftes det at blogg er et sosialt medium, for nederst gjør funksjonene det mulig å dele innlegg i andre sosiale medier som Facebook, Google og Instagram. I studentarbeidet brukes verktøyet i en institusjonell sammenheng, altså annerledes enn opprinnelig bloggbruk. I det totale materialet kommer det frem at disse delingsfunksjonene ikke brukes hyppig, og årsaken er nok at formålet er å utvikle kunnskap innenfor læringsfellesskapet. At bloggene er gjort ikke-søkbare, kan også knyttes til dette formålet. Det er tenkelig at institusjonell bloggbruk eventuelt kan bidra til å endre programvaren.

Nå har jeg sammenfattet hva slags komposisjonell meningsskaping bloggutsnittene inneholder, og går videre til å diskutere på hvilke måter en nivådelt analysemodell kan være hensiktsmessig i analyser av komposisjonell meningsskaping.

\section{Diskusjon av den nivådelte modellen for komposisjonsanalyse av bloggutsnitt}

I det følgende diskuterer jeg nærmere hvordan en nivådelt modell kan bidra til å belyse komposisjonell meningsskaping i multimodale tekster. Den nivådelte modellen er et metodologisk grep for analyse av komposisjon, blant annet fordi den bidrar til å strukturere analysen. Det er spesielt fire funn jeg mener viser modellens relevans.

For det første er det slik at overblikket som nivå 1 og 2, og til dels nivå 3 gir, kan oppfattes som orkestrering eller stillas for å stille anvendelige spørsmål. For eksempel: Hvor mye av komposisjonen har studenten satt sammen selv? Hvilke deler av komposisjonen kan være styrt av teknologi? Analysene viser 
tydelig at den komposisjonelle meningsskapingen i disse bloggutsnittene er en kombinasjon av mening som allerede er nedfelt i designmalene og meningsskapingen studentene selv designer innenfor de mulighetene som programvaren byr på. Et eksempel her er at det første bloggutsnittet (figur 4) bærer preg av at designmalen er innskrevet med typiske jentenormative trekk (Kvåle, 2018). Trekkene tydeliggjør at flere stemmer (Bakhtin, 1998 [1979]) har bidratt til den komposisjonelle meningsskapingen av bloggutsnittet, der både stemmene på produsentsiden (f.eks. teknologer og grafiske designere) og studentens designvalg tilsammen bidrar til å skape mening. Det at studenten har valgt en designmal som kan karakteriseres som jentenormativ, kan forstås som et meningsskapende poeng der bloggeren vil gi signaler om at hun er ei jente/dame som liker å uttrykke seg ved hjelp av hjerter og ornamentering. De barnlige semiotiske trekkene som ligger i denne første designmalen (figur 4), med søte, litt runde lekedyr i pastellfarger, sirlig løkkeskrift og et rødt hjerte-formet ikon som angir antall kommentarer (hjertet vises ikke i figur 4, men kommer til syne når leseren navigerer i bloggen), kan være et bevisst valg for å gi signaler om rollen studenten er i ferd med å innta som kommende barneskolelærer på småskoletrinnet. På denne måten formidler studenten at hun produserer denne bloggen, vel vitende om at utdanningen skal komme elever i småskolen til gode. Det er heller ikke utenkelig at studenten ønsker å skape et inntrykk av naivitet, for deretter å presentere en kontrast ved hjelp av innsiktsfulle og velreflekterte tekster. Da fungerer designmalen som et meningsskapende virkemiddel som overrasker leseren. Vi kan også tenke oss at valget av designmal kan fungere som visuell ironi, dersom studenten for eksempel ønsker å bryte kjønnsstigma og/eller konvensjoner. Studentene kan være kreative, og gjøre valg som skaper mening både mot og med produsentenes opprinnelige plan for hva designet kan signalisere. Nivå 1 og 2 kan anspore til slike refleksjoner i en analyseprosess.

I det andre bloggutsnittet ser vi et tittelbilde av bokrygger (nivå 2). Interessante spørsmål knyttet til denne komposisjonen kan være på hvilke 
måter bildets meningsskaping bidrar til å posisjonere bloggforfatteren i tillegg til å fortelle om innleggets tema. Dette er noen få eksempler på hva en ryddig analysestruktur kan utløse av interessante spørsmål knyttet til meningsskapingen. Analysemodellens nivå 1 og 2 gir anledning til å reflektere over mulighetene og begrensningene studentene har hatt tilgjengelig for å skape mening, og nivåene gir innsikt i hvilke meningsskapende modaliteter som faktisk er tatt i bruk. Et funn her kan være at en strukturell nivådelt modell kan lede den som analyserer digitalt medierte sakprosatekster til å stille interessante spørsmål.

For det andre bidrar den nivådelte modellen til at den som analyserer bloggutsnittene kan bevege seg fra det overordnede til det mer avgrensede og spesifikke. Å lede det analytiske blikket fra helhet til enhet, og deretter til å finne sammenhenger igjen, har vært en hensiktsmessig tilgang i disse analysene. Bloggutsnittene kan leses på ulike måter, avhengig av modaliteten som undersøkes. Verbaltekstlige blogginnlegg kan leses lineært, fra venstre mot høyre og ovenfra og nedover. Tegning og bilde oppfattes som romlige, visuelle tekster, og navigasjonsknapper eller trykkaktiv verbaltekst byr på interaktive muligheter, forutsatt at utsnittet leses på nettet. Dette viser varierte muligheter for meningsskaping og ulike muligheter for interaksjon i disse bloggutsnittene. Dette betyr at leseren hele tiden kan engasjere seg aktivt og på ulike måter for å finne mening i teksten. Dette kan forstås som et argument for at en systematisk nivådelt modell kan gi et godt grep om analyse av en tekst som består av ulike modaliteter. Dette kan også bety at det å bevege seg fra et overordnet nivå til det mer avgrensede og spesifikke, bidrar til at alle sider ved komposisjonen fanges opp, slik jeg mener å ha vist $i$ analysene i denne studien.

For det tredje kan den nivådelte modellen bidra til å synliggjøre hvor multimodal teksten egentlig er. I disse bloggutsnittene har den predefinerte rammen i tilknytning til innlegget flere modaliteter enn det vi finner i selve 
innlegget studenten har produsert. I innleggene finner vi verbaltekst og tegning, med ressurser som ulike fonter, avsnittsinndelinger som bidrar til å skape mening samt visualiseringer av utseende, klær, inntrykk av fremferd og blikk-vektorer i tegningene i de to innleggene. Mens i rammene i de to bloggutsnittene finner vi modalitetene som jeg har nevnt tidligere: Tittelbilder som skaper mening, fargede streker som har avgrensende funksjoner, ikoner knyttet til medstudenter, trykkaktiv verbaltekst og navigasjonsknapper.

I analysene har jeg vist at den nivådelte modellen fanger opp alle de semiotiske modalitetene: bilder, farger, avgrensning, innramming, verbaltekst, kontraster, farger/fargemetning, vektorer og variasjon gjennom ulike fonter, ikoner og navigasjons-muligheter. Nå foldes ikke hypertekstmulighetene ut i analysen, for premisset var å analysere bloggutsnittet komposisjonelt, som en visuell tekst. Analysene viser likevel de romlige dimensjonene i komposisjonen. Hypertekstualitet er et tekststruktureringsprinsipp, «en måte å organisere tekstsegmenter på» (Schwebs \& Otnes, 2006, s. 65). Muligheten for å navigere hypertekstuelt påvises tydelig i begge utsnitt på nivå 5 og 6 , i høyre vertikale kolonne og over og under innleggene. Ved hjelp av trykkaktive knapper og/eller tekst kan bloggeren navigere til både egne og andres blogger i læringsfellesskapet, og til eksterne nettsider for øvrig. Det multimodale omfanget fanges altså opp ved hjelp av den nivådelte analysemodellen.

For det fjerde gjør den nivådelte modellen det praktisk mulig å sammenligne likheter og/eller forskjeller i flere analyser av komposisjon i bloggutsnitt. Nivåene bidrar til at det går raskt å referere til tilsvarende poeng i andre analyser, slik jeg har vist i drøfting av meningsskapingen tidligere i oppsummeringen. Ved hjelp av min avgrensede analyse, ser vi at den nivådelte modellen bidrar til en henvisningspraksis der korrekte og avgrensede sammenligninger kan gjøres. For eksempel kan jeg oppgi at på nivå 3 har de to bloggutsnittene sammenfallende inndeling av vertikale kolonner. På nivå 1 
ser vi at utsnittene har ulik farge. I det første utsnittet, mellom nivå $1 \mathrm{og}$ innleggsfeltet i nivå 3, oppstår det en fargekontrast. Vi kan forstå det slik at kontrasten skaper en dybdefornemmelse, som om vi dykker ned i teksten. Dette var et eksempel på at nivåhenvisningene kan bidra til å gjøre sammenligninger mer transparente.

Ved hjelp av analysene har jeg nå vist hvordan en nivådelt modell kan være hensiktsmessig i en komposisjonell analyse av bloggutsnitt. Modellen har fungert som en strukturell ramme for å analysere det fremtredende, innramming og gitt og ny informasjon.

\section{Avsluttende kommentarer}

Den nivådelte analysemodellen jeg har undersøkt kan også tenkes å være hensiktsmessig å prøve ut i annen semiotisk forskning. Modellen kan ha relevans for bredere semiotiske analyser av mer enn komposisjonell meningsskaping. Da tenker jeg for eksempel på mer omfattende, visuelle innholdsanalyser av hvordan virkeligheten presenteres (representasjon) og hvordan menneskelige relasjoner skapes og opprettholdes (interaksjon) i multimodale tekster (Halliday \& Matthiessen, 2004; Kress \& van Leeuwen, 2006; Ledin \& Machin, 2018).

Jeg vil også argumentere for at den nivådelte analysemodellen kan anvendes på andre digitalt medierte sakprosatekster. Det finnes langt flere digitalt medierte tekster enn blogg som har tittelbilde, kolonner, moduler og lignende. Noen eksempler kan være hjemmesider, nettaviser, promoteringseller rekrutteringsnettsider eller offentlig informasjon på nettet. Mine funn kan være til nytte for lærerutdannere, og i neste omgang for studenter, for å øke søkelyset på viktigheten av bevisste formvalg, der hensikten er å utvikle designblikket. På denne måten kan studien gi en didaktisk retning for lærerutdanneren, gjennom at den nivådelte modellen representerer et stillas for 
studentarbeid med digitalt medierte tekster. Analysemodellen kan bidra til metabevissthet, og til å se mulighetene som ligger i design av nett-tekster. Denne studien kan informere videre forskning på digitalt medierte sakprosatekster.

Til slutt vil jeg rette søkelyset mot et potensial for videre forskning som ikke er utforsket nærmere i denne studien, men som er høyst relevant for alle analyser av digitalt medierte tekster, særlig fordi teknologien utvikler seg raskt. Da tenker jeg på forskningsfeltet semiotisk teknologi (Adami, 2015; Zhao et al., 2014; Zhao \& van Leeuwen, 2014). I nevnte studier handler det om, i tillegg til slike perspektiver jeg her har berørt, å undersøke ideologier, holdninger, verdier og makt som ligger til grunn for utformingen av programvaredesign. Sosiale og kulturelle oppfatninger er innbakt i designmaler i digitale verktøy. Dette feltet bør, etter min mening, vies mer forskningsinteresse fremover. 


\section{Referanser}

Adami, E. (2015). A Social Semiotic Perspektive on Digital Mobility. Media Education.Studies \& Research, 6(2), 184-2007.

Bakhtin, M. M. (1998 [1979]). Spørsmålet om talegenrane (omsett og med etterord av R. T. Slaattelid). Ariadne Forlag.

Björkvall, A. (2009). Den visuella texten. Multimodal analys i praktiken. Hallgren \& Fallgren Studieförlag AB.

Cope, B. \& Kalantzis, M. (2000). Introduction: Multiliteracies: The Beginning of an Idea. I B. Cope \& M. Kalantzis (Red.), Multiliteracies: Literacy Learning and the Design of Social Futures, 1-8. Routledge.

Djonov, E. \& Van Leeuwen, T. (2018). The power of semiotic software. A critical multimodal perspective. I J. Flowerdew \& J. E. Richardson (Red.), The Routledge handbook of critical discourse studies (s. 566-581). Taylor \& Francis.

Dysthe, O., Hertzberg, F. \& Hoel, T. L. (2010). Skrive for å lære. Skriving $i$ høyere utdanning 2. utg. Abstrakt forlag.

Halliday, M. A. K. (1978). Language as social semiotic : the social interpretation of language and meaning. Edward Arnold.

Halliday, M. A. K. \& Hasan, R. (1989). Language, Context and Text: Aspects of Language in a Social Semiotic Perspective. Oxford University Press. 
Halliday, M. A. K. \& Matthiessen, C. M. I. M. (2004). An introduction to functional grammar (3. utg.). Arnold.

Jewitt, C. (2006). Tecnology, Literacy and Learning. A multimodal approach. Routledge.

Jewitt, C. (Red.). (2014). The Routledge Handbook of Multimodal Analysis (2. utg.). Routledge.

Jewitt, C. \& Kress, G. (2003). Multimodal literacy. Peter Lang.

Jewitt, C. \& Oyama, R. (2001). Visual meaning: a social semiotic approach. I T. v. Leeuwen \& C. Jewitt (Red.), Handbook of Visual Analysis (s. 134-156). SAGE Publications.

Kress, G. (2003). Literacy in the New Media Age. Routledge.

Kress, G. (2010). Multimodality. A social semiotic approach to contemporary communication. Routledge.

Kress, G. \& van Leeuwen, T. (2006). Reading images: the grammar of visual design (2. utg.). Routledge.

Kress, G. \& van Leeuwen, T. (2021). Reading Images. The Grammar of Visual Design (Third edition. utg.). Routledge.

Kvåle, G. (2018). Bloggmaler som semiotisk teknologi og multimodalt halvfabrikat. En sosialsemiotisk analyse av stilrepertoaret til blogg.no. I M. Rogne \& L. R. Waage (Red.), Multimodalitet i skole- og fritidstekstar - ein vitskapleg antologi (s. 159-180). Fagbokforlaget/LNU. 
Ledin, P., Höög, C. N., Tønnesson, J. \& Westberg, G. (2019). Den multimodala sakprosan. Tidsskriftet Sakprosa, 11(4).

Ledin, P. \& Machin, D. (2018). Doing visual analysis : from theory to practice. SAGE.

Lüders, M., Prøitz, L. \& Rasmussen , T. (2010). Emerging personal media genres. New Media Society, 12(6), 947-963.

Melby, G. \& Matre, S. (Red.). (2012). A skrive seg inn i læreryrket. Akademika forlag.

Prensky, M. (2001). Digital Natives. Digital Immigrants. On the Horizon. MCB University Press, 9(5).

Rustand, K. A. (2019). Taste og tenke, mene og mestre. En tekstanalytisk studie av konstruksjoner av norsklæreridentiteter i multimodale bloggutsnitt (Publikasjonsnr. 39) [Doktorgradsavhandling, Universitetet i Sørøst-Norge]. Drammen.

Schwebs, T. \& Otnes, H. (2006). tekst.no strukturer og sjangrer i digitale medier (2. utg.). Landslaget for norskundervisning (LNU)/Cappelen Akademisk Forlag.

Stefanac, S. (2006). Dispatches from Blogistan: A Travel Guide for the Modern Blogger. New Riders.

Tønnesson, J. (2012). Hva er sakprosa (2. utg.). Universitetsforlaget. van Leeuwen, T. (2005). Introducing social semiotics. Routledge. 
van Leeuwen, T. \& Djonov, E. (2013). Multimodality and software. I C. C. Chapelle (Red.), Encyclopedia of applied linguistics. Wiley-Blackwell.

Zhao, S., Djonov, E. \& Van Leeuwen, T. (2014). Semiotic technology and practice: a multimodal social semiotic approach to PowerPoint. Text \& Talk, 34(3), 349-375.

Zhao, S. \& van Leeuwen, T. (2014). Understanding Semiotic Technology in University Classrooms: a Social Semiotic Approach to PowerPoint-Assisted Cultural Studies Lectures. Classroom Discourse, Taylor \& Frances Online, $5(1)$.

https://doi.org/https://www.tandfonline.com/doi/10.1080/19463014.2013.8 59848 